\title{
Introduction to Hegel's Theory of Tragedy
}

\author{
MARK W. Roche
}

Next to Aristotle's account of tragedy, the theory of tragedy developed by the German philosopher G. W. F. Hegel (1770-1831) has become the most studied and quoted in the West. Tragedy arises, according to Hegel, when a hero courageously asserts a substantial and just position, but in doing so simultaneously violates a contrary and likewise just position and so falls prey to a one-sidedness that is defined at one and the same time by greatness and by guilt.

Tragedy surfaces as a topic in Hegel's Phenomenology of Mind and his Lectures on the Philosophy of History, arguably his two best known works in the Anglo-American world. In chapter five of the Phenomenology Hegel discusses character, ethical action, and guilt partly by way of an analysis of Sophocles' Antigone. In his introduction to the Lectures on the Philosophy of History Hegel analyzes the world-historical individual who shapes history often beyond her conscious intentions; such figures emerge ahead of their time, come into conflict with their ages, and prepare a new world. In his Lectures on the History of Philosophy Hegel offers a fascinating portrait of Socrates in the light of this tragic dialectic. Also in his Lectures on the Philosophy of Religion Hegel touches on tragedy, especially in the Greek world and in relation to reconciliation.

Tragedy is most prominent in Hegel's Lectures on Aesthetics, which is one of his most accessible texts. The Aesthetics, which was compiled and edited by Hegel's student Heinrich 
Gustav Hotho, is based on Hegel's lecture notes and on student transcriptions of the lectures. Hegel lectured on aesthetics in Heidelberg in 1818 and in Berlin in 1820/21, 1823, 1826, and 1828/29. Toward the end of his lectures Hegel discusses drama and devotes most of his attention to tragedy. These reflections represent Hegel's most mature and most extended discussion of tragedy. ${ }^{1}$

For Hegel tragedy is the conflict of two substantive positions, each of which is justified, yet each of which is wrong to the extent that it fails either to recognize the validity of the other position or to grant it its moment of truth; the conflict can be resolved only with the fall of the hero.

The original essence of tragedy consists then in the fact that within such a conflict each of the opposed sides, if taken by itself, has justification, while on the other hand each can establish the true and positive content of its own aim and character only by negating and damaging the equally justified power of the other. Consequently, in its moral life, and because of it, each is just as much involved in guilt (15:523, A 1196, translation modified). ${ }^{2}$

Hegelian tragedy is the inevitable consequence of the absolute realizing itself in history. In the course of history, one-sided positions emerge that contain within themselves their own limitations (15:486, A 1167). These positions give rise to conflicts, which are resolved in each case by the transcendence (or death) of the particular, such that history progresses dialectically, through contradiction and negativity, toward an ever more comprehensive and rational goal.

Precisely because tragedies of collision frequently arise during paradigm shifts, Hegel is attuned to historical conflicts, crises, and transitions. Hegel invites audiences to ask: Which values have come into conflict? Which positions are rooted in the past and which are harbingers of the future? In what ways do individual characters embody the conflicting strands of history? To what extent are forces beyond the hero's intentions and passions shaping the events as they unfold? The importance of historical drama has been developed partly under Hegelian influence by the 
nineteenth-century German dramatist Friedrich Hebbel (1813-1863), who tries to show the clash of values as one norm is pushed aside and another comes into being. Often a self-sacrificing hero arrives before a new paradigm is set and collides with tradition, or a stubborn hero holds on to her position long after a new norm has taken shape. For Hegel the individual can be morally right, and the state retrograde, such that an individual may be more aligned with the universal, the state more with the false particularity that must ultimately give way (or adjust to the ideas represented by the moral individual). In this sense we should be careful not to see in Hegel's view simply a deflation of the value of the person in the march of history. Many tragic heroes stand for truths that are too new to have a majority behind them; after the hero's sacrifice the situation will change:

That is the position of heroes in world history generally; through them a new world dawns. This new principle is in contradiction with the previous one, appears as destructive; the heroes appear, therefore, as violent, transgressing laws. Individually, they are vanquished; but this principle persists, if in a different form, and buries the present (18:515).

Because the tragic hero acts both for and against the good, her nature is as paradoxical as the situation in which she finds herself: she is both great and flawed—indeed, her very greatness is her flaw, since greatness comes at the price of excluding what the situation demands. The hero is both innocent and guilty—innocent insofar as she adheres to the good by acting on behalf of a just principle; guilty insofar as she violates a good and wills to identify with that violation. Guilt presupposes action for which the hero is responsible; as a result, the hero seeks not sympathy or pity but recognition of the substance of her action, including its consequences. In this spirit Hegel 
offers the paradoxical formulation: "It is the honour of these great characters to be culpable" (15:546, A 1215).

Most interpreters of tragedy, beginning already with Aristotle, focus their accounts of tragedy on the effect of tragedy, on its reception. Hegel, along with Friedrich Hölderlin (17701843), Friedrich Schelling (1775-1854), and Peter Szondi (1929-1979), is one of the few figures in the tradition to take a different path. Hegel focuses on the core structure of tragedy. And yet Hegel's focus on the structure of tragic collision gives him a new angle on the traditional motifs of fear and pity. For Hegel the audience is to fear not external fate, as with Aristotle, but the ethical substance which, if violated, will turn against the hero (15:525, A 1197-98). Insofar as suffering flows inevitably from the tragic hero's profound identification with a just and substantial position, suffering for Hegel is not quite the undeserved suffering that for Aristotle elicits pity. Hegel reinterprets pity as sympathy not merely with the suffering hero as sufferer but with the hero as one who, despite her fall, is nonetheless in a sense justified. According to Hegel, we fear the power of an ethical substance that has been violated as a result of collision, and we sympathize with the tragic hero who, despite having transgressed the absolute, also in a sense upholds the absolute. Thus, Hegelian tragedy has an emotional element: we are torn between the values and destiny of each position; we identify with the character's action but sense the inevitable power of the absolute, which destroys the hero's one-sidedness.

Not only does the tragic hero refuse to acknowledge the validity of the other position, but the other position—or at least the sphere it represents—is also an aspect within the hero even as she denies it. This is especially clear in Sophocles' Antigone, which Hegel describes as the most 
beautiful of all tragedies (15:550, A 1218; see also 17:133). According to Hegel, the action of each hero is shown to be not only destructive of the other but ultimately self-destructive. Antigone is not only a family member but a member of the state, Creon not only a ruler but a father and husband. The tragic heroes transgress "what, if they were true to their own nature, they should be honouring" (15:549, A 1217-1218). In addition to this dialectic of positions, Hegel notes that Creon and Antigone are equally stubborn and steadfast; both fail to recognize a legitimate conflict of goods, and each is as single-minded as the other.

Hegel not only sees value on each side, he goes so far as to claim that the tragic heroes embrace conflicting positions that are "equally justified” (15:523, A 1196; cf. 3:349). Hegel cannot be right when he says that all tragic collisions contain poles of equal value; this is already clear in the problems classical philologists have found in Hegel's otherwise magisterial reading of Antigone. Certainly Hegel himself, as we can see from the very language he uses to describe her, is more sympathetic toward Antigone. Nonetheless, Hegel is right if we understand him to mean that in the best tragedies the conflict is equal. In works where the conflict is unequal, tragic intensity tends to diminish.

Indeed, the Hegelian collision of two goods is in principle the dramatically richest form of tragedy. Even Arthur Schopenhauer (1788-1860), who develops a concept of tragedy in The World as Will and Representation that is far removed from Hegel's reconciliatory focus, privileges that form of tragedy defined by a collision of goods; it is the most dramatic and most powerful. Our understanding of a work that seemingly lacks a collision may be enriched by a reading that 
recognizes submerged moments of collision. One might, for example, emphasize the elements of tragic collision in works such as Euripides’ Bacchae, Schiller's Wallenstein, Ibsen’s Ghost, or Brecht's The Good Person of Sezuan.

Whereas the most dramatic form of tragedy arises when the poles are embodied in two characters or institutions, Hegel also discusses the possibility of a tragic collision within an individual's consciousness. An internal collision of this kind may become less dramatic because of the unity of two positions within a single self; however, internal collisions tend to be intellectually and psychologically more differentiated. They allow for richer characterization, a trait Hegel admired in modern drama. Internal collision is also formally rich, giving rise to some of the greatest rhetoric of world drama, monologues and dialogues that presuppose awareness of an ineradicable conflict of goods. That the hero must sacrifice her naive belief in a just world—by violating one good in order to preserve another-has extraordinary intellectual and emotional consequences.

The danger may of course arise that the hero will simply waver back and forth between one pole and the other, thus destroying her resolve and any unity of character, and that this indecisiveness, not the substance of the poles, will be heralded as the essence of art (13:312, A 241; 15:562-63, A 1228-29). In this context, Hegel distinguishes characters who hesitate because they are confused and weak from those who see a genuine and irresolvable conflict of goods.

It is already different if two opposed spheres of life, duties, and so forth, seem equally sacrosanct to a self-assured character, and yet he sees himself compelled to align himself with one to the exclusion of the other. In that case the vacillation is only a transitional phase and does not constitute the nerve of the person's character (15:563, A 1228-9, translation modified). 
A central insight in Hegel's analysis of tragedy in the Phenomenology is that, even when the tragic hero becomes conscious of the justice of a competing position, character demands consistency and, with this, not vacillation, but action, acknowledgment, and guilt (3:348).

Whereas Aristotle, as well as certain formal theorists in the twentieth century, developed ahistorical theories of tragedy, and contemporary critics tend to dispute any transhistorical concept of genre, Hegel was aware of both, offering a universal definition, but suggesting at least one significant shift in its articulation, the difference between ancient and modern tragedy. In ancient tragedy the characters completely identify with the substantive powers and ideas that rule human life; characters act "for the sake of the substantial nature of their end" (15:558, A 1225). In modern tragedy, in contrast, we see greater internal development of character as well as the elevation of more particular concerns: "what presses for satisfaction is the subjectivity of their heart and mind and the privacy of their own character” (15:558, A 1225). Also the complexity of modern causality diminishes the extent to which one single person can affect the world around her; complexity and the contingency of circumstances play a greater role in modern tragedy $(15: 537$, A 1207; 15:558, A 1224; 15:560, A 1226).

For Hegel tragic fate is rational: reason does not allow individuals to hold on to one-sided positions. Because each stance is constituted through its relation to the other, the elimination of one stance leads to the destruction of the other. The human result is death, but the absolute end is the reestablishment of ethical substance. This unity is for Hegel the catharsis of tragedy, which takes place in the consciousness of the audience, as it recognizes the supremacy of the whole of ethical 
life and sees it purged of one-sidedness. The tragic hero adheres to a one-sided position, denies the validity of its complementary and contrasting other, and eventually succumbs to the greater process in which it is submerged. The tragic adherence to a partial position is stripped away and yields to the larger rational process of historical development. Tragedy thus contains within itself a hidden moment of resolution and reconciliation (15:524, A 1197; 15:526, A 1198; 15:547, A 1215). This elevation of harmony in tragedy has often been criticized, especially in modernity. Rare is the modern reading of tragedy that sees in tragedy even a glimmer of reconciliation or rational order.

Hegel introduced along with tragedy a neighbouring genre, the drama of reconciliation, which greatly interested such early Hegelians as Carl Ludwig Michelet (1801-1893) and Moritz Carriere (1817-1895). Some of the contradictions in Hegel's overvaluing of reconciliation may have derived from his failure to differentiate these two genres adequately. Though there is a connection between catharsis and reconciliation, a significant difference exists between tragedy and the drama of reconciliation, namely, whether reconciliation takes place in reception, that is, in the consciousness of the audience, or in the storyline itself, that is, on stage. Hegel mentions in this context Aeschylus’ Eumenides and Sophocles' Philoctetes as well as Goethe’s Iphigenia, which Hegel elevates even higher than the Greek plays insofar as its harmonious resolution is unambiguously organic, deriving as it does from the action itself (15:532-33, A 1203-04). In his Lectures on the Philosophy of Religion Hegel returns to this elevation of resolution, arguing again for a transcendence of tragedy, whereby the heroes overcome one-sidedness not through death but in their mind and action (17:134; cf. 15:550-51, A 1219). 
Unfortunately, Hegel never fully develops his brief discussion of the drama of reconciliation, and when he does return to it, his comments are as frequently derogatory as they are laudatory. The form is "of less striking importance" (15:531, A 1202). It runs the danger of not fully developing a conflict (15:533, A 1204). The hero who alters his position may appear to lack character (15:550, A 1218). Such changes may diminish the determination and pathos of the hero's position (15:568, A 1233). Finally, harmonic resolutions are frequently unearned (15:569, A 1233). Most of these points can weaken a drama of reconciliation, but they do not belong to it in principle. Hegel himself seems unsure whether these characteristics are contingent or necessary. If Hegel were to have analyzed the drama of reconciliation more fully and stressed more clearly the difference between it and tragedy, he may not have been led to overstress the reconciliatory moment within tragedy itself. To a degree the critics who assert that Hegel over-idealizes tragedy and gives insufficient attention to the moment of ineradicable suffering are right: the genre is not exhausted by its harmonic resolution; tragedy also suggests the inevitable calamities and inconsolable suffering that result when greatness surfaces in a complex world. On the other hand, it is equally one-sided to assert, as many contemporary critics do, that tragedy offers us only destruction, uncertainty, and gloom, and that any hidden visions of greatness, harmony, or hope are anathema to the tragic spirit. Tragedy is too multifaceted and complex for such an either-or reception. $^{3}$ 


\section{Notes}

1. Anne and Henry Paolucci have gathered into one volume Hegel's various comments on tragedy. See Hegel on Tragedy.

2. All references to Hegel are to his collected works (indicated by volume number and page number). The most accessible edition of Hegel's collected works is the Werke in zwanzig Bänden, containing volumes 13, 14, and 15 of the Hotho edition of the Aesthetics. Although other editions of the Aesthetics are available in German, they are restricted to student transcriptions of single lectures. The Hotho edition, though filtered through Hotho's own thinking, is the most comprehensive edition. Most of the passages cited here stem from the Aesthetics. In those instances I have also given page numbers to the two-volume translation of T. M. Knox, prefaced by the letter A. This is the standard English translation of Hegel's Aesthetics, which is based on the Hotho edition.

3. For fuller accounts of Hegel's theory of tragedy, with reference to the secondary literature, see my essay "The Greatness and Limits of Hegel's Theory of Tragedy" or my book Tragedy and Comedy: A Systematic Study and a Critique of Hegel.

\section{Works Cited}

Hegel, G.W.F. Hegel's Aesthetics: Lectures on Fine Art. Trans. T. M. Knox. Oxford: Clarendon, 1975.

—. Werke in zwanzig Bänden. Ed. E. Moldenhauer and K. M. Michel. Frankfurt: Suhrkamp, 1970.

Paolucci, Anne and Henry Paulucci. Hegel on Tragedy. New York: Doubleday, 1962.

Roche, Mark W. “The Greatness and Limits of Hegel's Theory of Tragedy.” A Companion to Tragedy. Ed. Rebecca Bushnell. Oxford: Blackwell, 2005. 51-67.

-. Tragedy and Comedy: A Systematic Study and a Critique of Hegel. Albany: State University of New York Press, 1998. 